\title{
A Capillary Angioma of the Lips: An Extremely Rare Situation in the Oral Cavity
}

\author{
Angioma Capilar de los Labios: Una Situación \\ Extremadamente Rara en la Cavidad Oral
}

\author{
Amminou, Loubna ${ }^{1}$ \& El Harti, Karima²
}

\begin{abstract}
AMMINOU L. \& EL HARTI, K. A capillary angioma of the lips: An extremely rare situation in the oral cavity. Int. J. Odontostomat., 14(3):354-357, 2020.

ABSTRACT: Hemangiomas are tumors identified by rapid endothelial cell proliferation in early infancy, followed mostly by involution over the time. However, $10-12 \%$ of true hemangiomas don't involute and require surgical treatment. Hemangiomas are classified on the basis of their histological appearance as capillary, mixed and cavernous. We report a case of capillary angioma in a 13-year old boy who presented with a budding into the lower lip. The lesion was excised and histopathological report confirmed the diagnosis.
\end{abstract}

KEY WORDS: capillary angioma, lips.

\section{INTRODUCTION}

Oral cavity hemangiomas are not commonly encountered by general dentists. In fact, hemangiomas are rarely seen in the oral cavity especially in the oral soft tissue (Handa et al., 2013).

The term "hemangioma" is derived from the Greek term "hema" denoting "blood," 'angio' denoting "vessel," and the suffix-oma denoting "tumor" (Nagaraj et al., 2016).

We conclude that this appellation specifies that they are tumors, however, some authors believe that they are true neoplasm while others claim that they are hamartomatous lesions (Sepulveda et al., 2013).

Hemangiomas can occur as isolated lesions in the oral cavity or as multiple lesions in different parts of the body. They can also be associated with other developmental anomalies in the various angiomatous syndromes such as Osler-weber-Rendu syndrome or Hereditary Haemmorhagic Telengiectasia (Karthik et al., 2017).

Hemangiomas are classified on the basis of their histological appearance. Capillary hemangioma is the most common type, it occurs as a small localized lesion and has the less-aggressive clinical behavior (da Silva et al., 2014). Its most common presentation is the port-wine stain. In the soft tissue it can appear as a soft mass, smooth or lobulated, sessile or pedunculated and may be seen in any size from a few millimeters to several centimeters. It can have a superficial seating or deeply one (higher hemorrhagic risk) (Karthik et al.).

In this case, we are presenting a rarely case of capillary hemangioma in the lower lips that was removed by simple excision due to his small size and superficial seating.

\section{CASE REPORT}

A 13-year-old Moroccan boy was referred by his dentist to the Department of oral surgery in the Faculty of Dentistry at Rabat for evaluation and treatment of lesion appearing in the lips.

The interview revealed no particular antecedent and the patient had no health problems.

\footnotetext{
${ }^{1}$ Resident in the department of oral surgery, Faculty of Dentistry of Rabat, Mohammed V University Morocco.

2 Professor of oral surgery, Faculty of Dentistry of Rabat, Mohammed V University Morocco.
} 
The patient consulted previously with general practitioners who prescribed antimicrobial and local treatments without improvement.

Exobuccal examination showed lesion in the lower lip on the left side, red, round measuring around $1.5 \mathrm{~cm}$. At the level of its surface we noticed a crusty ulceration (Fig. 1).

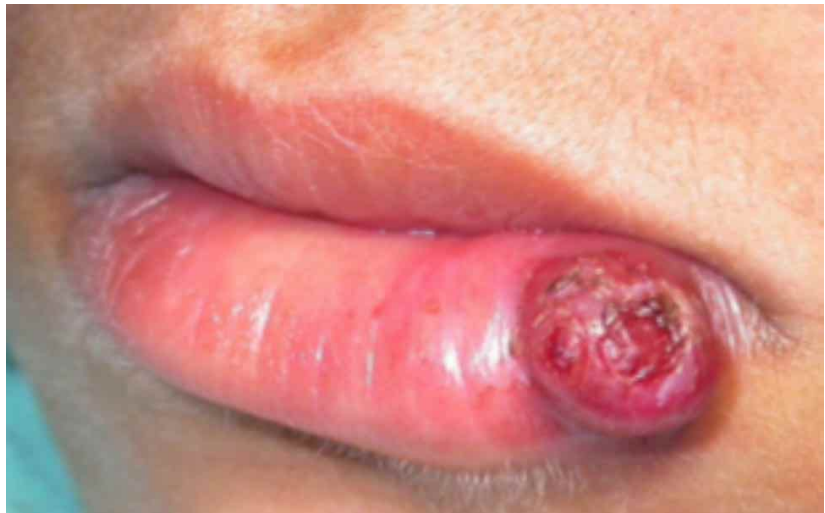

Fig. 1. Exooral view showing a red lesion located on the right side of lips.

On palpation the lesion was compact, not painful. The crusty ulcerations were easily removed. No lymphadenopathy was palpable.

In view of the clinical examination carried out, the diagnosis referred to were pyogenic granuloma, squamous cell carcinoma and angioma.

The treatment of the lesion consisted of an exeresis biopsy in view of the small size of the lesion (Fig. 2).

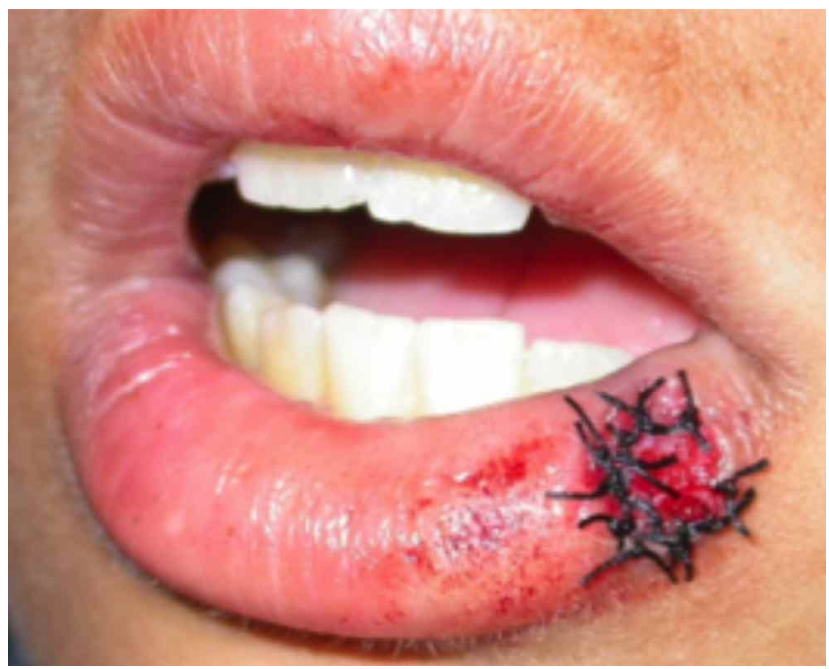

Fig. 2. Postoperative view immediately After excision of the lesion.
After anesthesia was administered all around the lesion, the latter was taken with tweezers, and the tumor was subsequently carefully removed using a blade (Fig. 3).

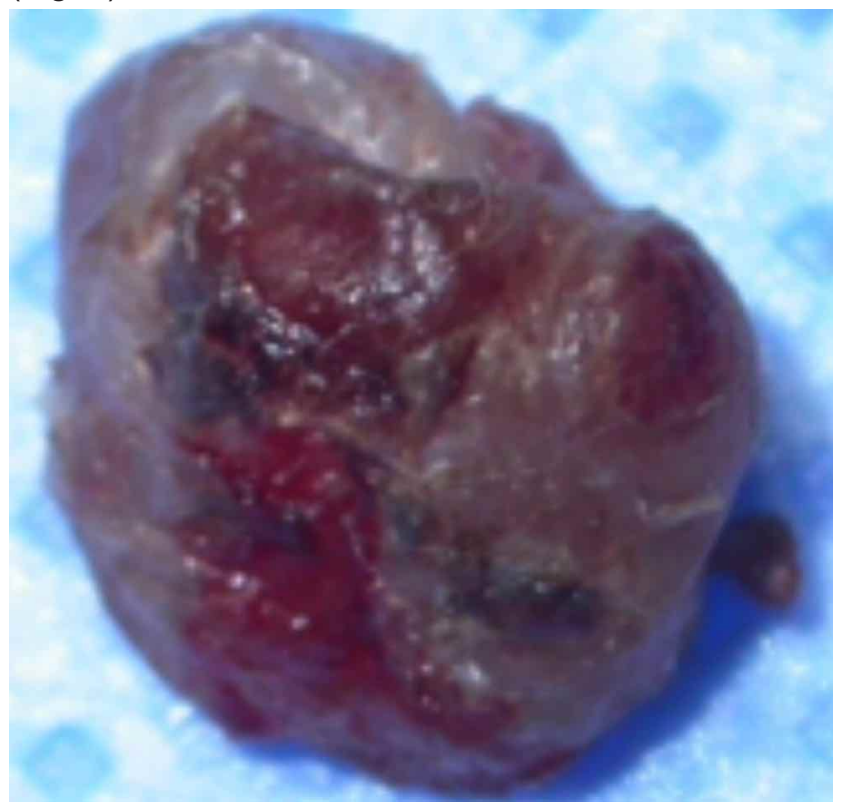

Fig. 3. Excised lesion.

A slight bleeding accompanied the surgery and was controlled by compression.

The excised tissue was kept in formalin (10\%) and sent for histopathologic examination.

An analgesic treatment was prescribed for the patient.

The patient responded well to the treatment, and was kept on maintenance visits for 6 months (Fig. 4). To date no recurrence has been reported.

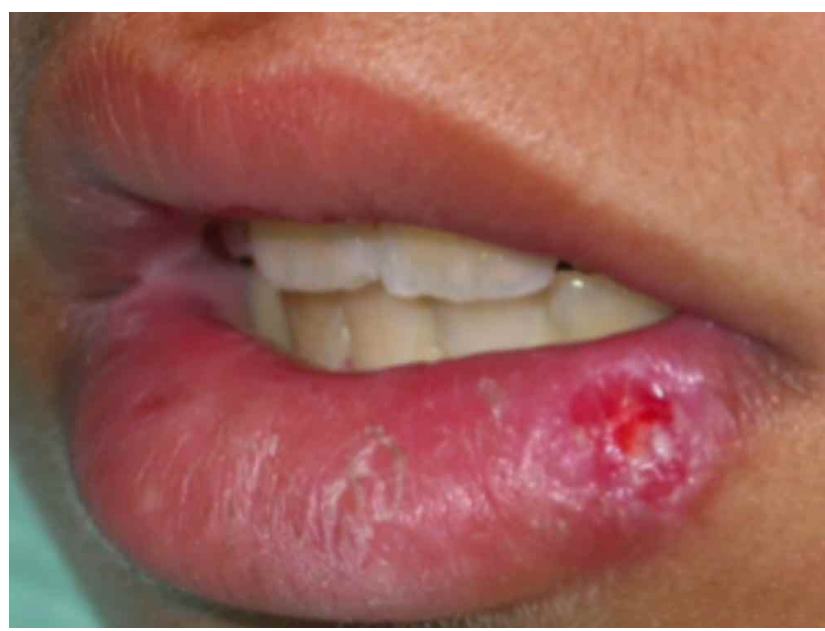

Fig. 4. Site of the lesion after 1 week of surgery. 


\section{DISCUSSION}

Haemangiomas are considered to be benign tumors of infancy (7\%), affecting as many as $12 \%$ in white people, but they rarely occur in dark-skinned individuals (Kumari et al., 2015).

They usually cover a large site, may be macular or raised and usually resolve progressively in childhood (Handa et al.).

Capillary hemangioma is a benign proliferation of blood vessels that primarily occurs during childhood (Jananni et al., 2012). Occasionally, older individuals are affected (Karthik et al.).

Capillary hemangioma can be found in different sites such as eyelid, cheek and cauda equine (Handa et al.). The incidence of intraoral capillary haemangiomas is extremely rare, and varies from 0.5 $1.0 \%$ of all intraoral neoplasms, especially with female predilection (ratio of 3:1) in second and third decades of life (Kumari et al.).

Nayouki Matsumoto studied 31 cases of intra oral capillary haemangioma and found that most lesions were located on buccal mucosa $(45.2 \%)$, followed by the tongue (35.5\%), lip (9.7\%), gingiva (6.5\%), and palate $(3.2 \%)$ (Kumari et al.).

Capillary hemangioma may be cutaneous, involving skin, lips and deeper structures; mucosal, involving the lining of the oral cavity; intramuscular, involving masticator and perioral muscles; or intraosseous, involving mandible and/or maxilla (Dilsiz et al., 2009).

The etiology of hemangioma has not been fully elucidated (Dilsiz et al.; Parimi et al., 2016). Imbalance in angiogenesis plays an important role in the development of hemangiomas (Parimi et al.).

Histologically, hemangioma can be divided into three groups: Cavernous, is the most frequent one and is located in the mandible, they can be capillary and mixed (Dhiman et al., 2015).

They are classified on the basis of their histological appearance. Capillary and cavernous hemangiomas are defined according to the size of vascular spaces. Capillary hemangioma are composed of small thin walled vessels of capillary size, that are lined by a single layer of flattened or plump endothelial cells and surrounded by a discontinuous layer of pericytes and reticular fibers (Dilsiz et al.; Karthik et al.).

Cavernous hemangiomas consist of deep, irregular, dermal blood-filled channels. They are composed of tangles of thin-walled cavernous vessels or sinusoids that are separated by a scanty connective tissue stroma. Mixed hemangiomas contain both components and may be more common than the pure cavernous lesions (Dilsiz et al.; Karthik et al.).

Capillary hemangioma occurs as a small localized lesion and has less-aggressive clinical behavior, in contrast to the cavernous hemangioma which is most aggressive and generates large and infiltrated lesions (da Silva et al.).

The differential diagnosis of capillary hemangiomas includes pyogenic granuloma. This entity has clinical aspects in common, radiographically or even histologically. Pyogenic granuloma called "lobular capillary hemangioma" presents a very striking resemblance, however, the difference remains unclear (Rachappa \& Triveni, 2010; Handa et al.; Kumari et al.).

Other diagnosis to be compared as such, are: chronic inflammatory gingival hyperplasia (epulis), epulis granulomatosa, squamous cell carcinoma (Jananni et al.) and peripheral ossifying fibroma (Handa et al.; Kumari et al.).

The diagnosis is definitive only when a biopsy is combined, given the similarity of the clinical features between the pyogenic granuloma. In the same way, the malignant process may be confirmed (Rachappa \& Triveni).

The treatment of angioma is indicated only when there is impairment of function (discomfort, repetitive bleeding), aesthetics disfigurement or when faced with an evolutionary form (Dhiman et al.).

The range of treatment includes surgery, laser therapy, use of sclerosing agents, embolization and corticosteroid therapy (Jananni et al.; da Silva et al.).

The treatment of hemangiomas of the oral mucosa depends upon various factors such as the age of the patient, the size of the lesion, extent of the lesion, the site of involvement, and the clinical features (Parimi et al.). 
In this case, surgical treatment was chosen because of the small size of the lesion, its accessible site and the absence of bleeding on the palpation of the mass (low risk of bleeding).

\section{CONCLUSION}

Oral cavity capillary hemagiomas are rare. Their diagnosis must be taken into account each time it is suspected, so that the treatment choice will be reviewed and proper safety measures can be taken before any surgery.

In our case, the lesion was small and superficially located, so surgery was the best choice. However, other treatments could be proposed depending on the case.

AMMINOU, L. \& EL HARTI, K. Angioma capilar de los labios: Una situación extremadamente rara en la cavidad oral. Int. J. Odontostomat., 14(3):354-357, 2020.

RESUMEN: Los hemangiomas son tumores identificados por la rápida proliferación de células endoteliales en la primera infancia, seguidos principalmente por involución a lo largo del tiempo. Sin embargo, entre el 10 y el $12 \%$ de los hemangiomas no intervienen y no requieren tratamiento quirúrgico. Los hemangiomas se clasifican en función de su aspecto histológico como capilares, mixtos y cavernosos. Reportamos un caso de angioma capilar en un niño de 13 años que presentó un brote en el labio inferior. La lesión fue extirpada y el informe histopatológico confirmó el diagnóstico.

PALABRAS CLAVE: angioma capilar, labios.

\section{REFERENCES}

da Silva, W. B.; Ribeiro, A. L.; de Menezes, S. A.; de Jesus Viana Pinheiro, J. \& de Melo Alves-Junior, S. Oral capillary hemangioma: a clinical protocol of diagnosis and treatment in adults. Oral Maxillofac. Surg., 18(4):431-7, 2014.

Dhiman, N. K.; Jaiswara, C.; Kumar, N.; Patne, S. C.; Pandey, A. \& Verma, V. Central cavernous hemangioma of mandible: Case report and review of literature. Natl. J. Maxillofac. Surg., 6(2):20913, 2015.

Dilsiz, A.; Aydin, T. \& Gursan, N. Capillary hemangioma as a rare benign tumor of the oral cavity: a case report. Cases J., 2:8622, 2009.

Handa, R.; Sheikh, S.; Shambulingappa, P.; Aggarwal, A.; Mago, J. \& Salaria, S. Capillary hemangioma of palate: a case report. Pak. Oral Dent. J., 33(1):55-7, 2013.

Jananni, M.; Gubernath, U.; Mahendra, J. \& Sivaramakrishnan, M. Capillary hemangioma of gingiva mimicking as pyogenic granuloma: Report of two cases. J. Interdiscip. Dent., 2(3):21820, 2012.
Karthik, R.; Mohan, N.; Fenn, S. M.; Ravikumar, P. T. \& Gokulraj, S. A capillary hemangioma on the gingiva of an adult associated with a Phlebolith - A rare case report. J. Oral Med. Oral Surg. Oral Pathol. Oral Radiol., 3(1):56-61, 2017.

Kumari, V. R.; Vallabhan, C. G.; Geetha, S.; Nair, M. S. \& Jacob, T. V. Atypical presentation of capillary hemangioma in oral cavity A case report. J. Clin. Diagn. Res., 9(10):ZD26-8, 2015.

Nagaraj, T.; Nigam, H.; Balraj, L. \& Gogula, S. Hemangioma: a rarest entity. J. Med. Radiol. Pathol. Surg., 3(6):19-22, 2016.

Parimi, S.; Kubbi, J. R.; Tipirisety, S. \& Kalepu, V. K. Intraoral capillary haemangioma: A rare case report. J. Indian Acad. Oral Med. Radiol., 28(3):296-9, 2016.

Rachappa, M. M. \& Triveni, M. N. Capillary hemangioma or pyogenic granuloma: A diagnostic dilemma. Contemp. Clin. Dent., 1(2):11922, 2010.

Sepulveda, I.; Spencer, M. L.; Platin, E.; Trujillo, I.; Novoa, S. \& Ulloa, $D$. Intraosseous hemangioma of the mandible: case report and review of the literature. Int. J. Odontostomat., 7(3):395-400, 2013.

Corresponding author:

Dr Amminou Loubna

Faculté de Médecine Dentaire de Rabat

BP 6212 Rabat

Institute Rabat

MOROCCO

Email: loubnamminou@gmail.com

Received: 10-02-2020

Accepted: 09-03-2020 